\title{
Altruism a Piety in Philanthropy Visualization on YouTube: Case Study Hobby Makan Channel
}

\author{
$1^{\text {st }}$ Nurhablisyah ${ }^{1}, 2^{\text {nd }}$ JM. Muslimin ${ }^{2}, 3^{\text {rd }}$ Asep Saepudin Jahar ${ }^{3}, 4^{\text {th }}$ Usep Abdul Matin ${ }^{4}$, \\ $5^{\text {th }}$ Asmawi $^{5}, 6^{\text {th }}$ Imam Sujoko ${ }^{6}$ \\ \{nurhablisyah@gmail.com ${ }^{1}$, muslimin@uinjkt.ac.id ${ }^{2}$, asepjahar@uinjkt.ac.id ${ }^{3}$, \\ usep.abdulmatin@uinjkt.ac.id ${ }^{4}$, asmawi@uinjkt.ac.id ${ }^{5}$, imam.sujoko@uinjkt.ac.id ${ }^{6}$ \}
}

Indrarasta PGRI University, Jakarta, Indonesia ${ }^{1}$, Sy arif Hiday atullah State Islamic University of Jakarta, Indonesia ${ }^{2,3,4,5,6}$

\begin{abstract}
This study attempts to illustrate the Hoby Makan channel on youtube as messages of philanthropic activities. The video visualization on this channel consists of four components: (1) Thumbnail, which consists of texts and pictures, (2) Opening, location of the street food, (3) Main contents: reviewing food and its texture, (4) Closing: delivering persuasive words about religious messages. The religious messages are delivered by saying a common statement "Borong Semua" (all of them) to share and participate in helping disadvantaged people. This statement has soon become famous and has inspired similar channels to do the same. The Hobby Makan channel has shown altruism and piety through philanthropic activities in its videos. As a YouTuber with more than 3 million subscribers, Hobby Makan has the power to influence people. Its videos have inspired another YouTuber to do the same. This study, therefore, aims at illustrating how fundraising innovation through electronic technology has been adapted to a current trend in millennial society. As a qualitative case study to analyze phenomena, a semiotic approach is applied to analyze the channel contents or message. As the result, the study shows an increasing approach and innovation in philanthropic activities in $d a^{6} w a h$.
\end{abstract}

Keywords: Philanthropy, Visualization, Hobby Makan, YouTube Channel.

\section{Introduction}

In its 2018 report, APJII/Asosiasi Penyelenggara Jasa Internet Indonesia (Indonesian Internet Service Providers Association) mentions the number of internet users in Indonesia in 2017 is 143,26 million. This number has increased more than 10,000 compared to 2016. Most of them have used internet for chatting $(89,35 \%)$, social media $(87,15 \%)$, search engine $(74,84 \%)$, seeing pictures $(72,79 \%)$ and watching video $(69,64 \%)$. Watching videos becomes the five top list of users ' activities in their daily life [1]. YouTube has earned its popularity in Indonesia since 2010 when Sinta and Jojo lip-syncing "Keong Racun" video went viral among Indonesian. Their video struck a massive hit. Since then, Indonesians have loved watching YouTube which has gradually taken over TV station audiences [2]. Since its launch in 2005, YouTube has attracted millions of people around the world. In 2010, Google bought YouTube with $\$ 1,65$ Billion and boosted the viewers up to 700 million in a week. At present, about 1 million videos are uploaded every day [3]. 
According to medium.com, Indonesia is nominated as the Top 25 Countries with the mo st YouTube viewers. It ranks 18th place. It even ranked 16th place of the Top 25 Countries with the most YouTube viewers, in 2019 [4]. USA, India, UK, South Korea, Brazil, Thailand are nominated as the top 10 countries with the total YouTube views. One main issue for Indonesian people to watch YouTube is internet access, which is still expensive in this country.

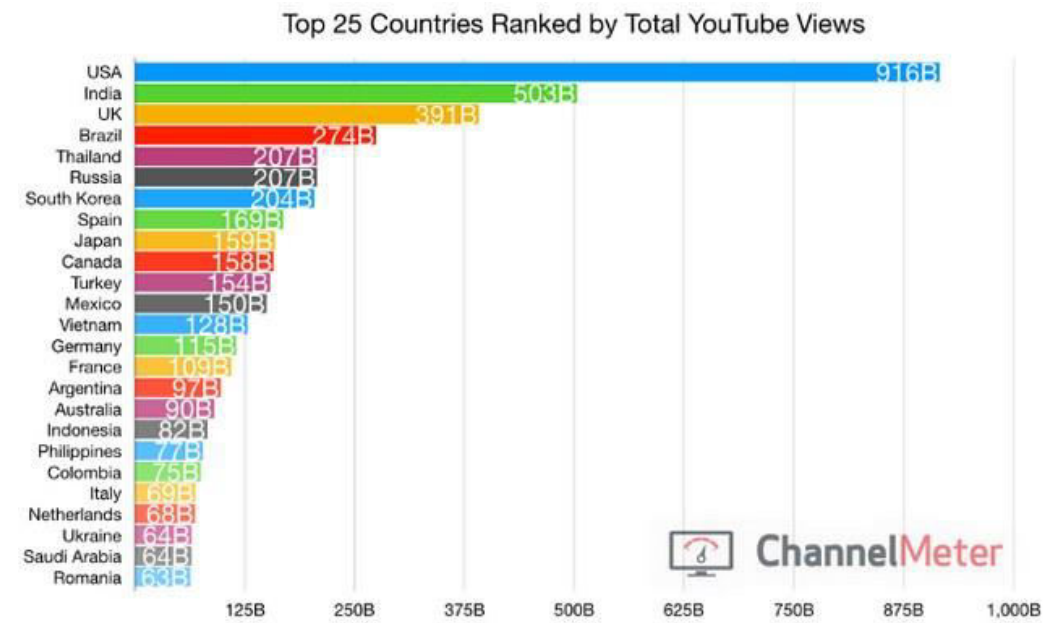

Fig. 1. Top 25 Countries Ranked by Total YouTube Views

(Source: https://medium.com/@ChannelMeter/YouTubes-top-countries-47b0d26dded)

This phenomenon has opened up a new opportunity for many people to work as YouTubers. They can use their creativity to create videos and upload them on YouTube. The Indonesian YouTubers who have reached the most number of subscribers in East Asia are Atta Halilintar and Ria Ricis. There are about 79 million active viewers and 340 channels earning silver buttons [5].

In terms of business, a YouTuber gains two benefits, online popularity, and increasing income. Some Indonesian YouTubers have even become billionaires with a dramatic increase in income every month, among others, (1) Zuni and Family income is worth IDR 193,2 billion per year, (2) DeHakim with IDR 84 billion, (3) Rans Entertainment with IDR 84 Billion, (4) Bapau (Baim Paula) with IDR74,1 Billion, (5) Gen Halilintar with IDR 63 billion, (6) Praya Brother with IDR58,8 Billion, (7) Ria Ricis with IDR47,6 Billion, (8) Arif Muhamad with IDR46,2 million, (9) Atta Halilintar with IDR44,8 Billion, and (10) Deddy Corbuzier with IDR 43,4 Billion respectively[6].

Hobby Makan Channel was created in 2017 by Evan and Tiwi, a married couple from Pontianak. Their subscribers have reached 3,84 million in August 2020. In the beginning, their content was about food cooking and street food reviews in Pontianak. However, they changed their video concept in 2019. Since then, they have not only conducted food reviews but have also given charity to mobile street food vendors. They like traveling around Indonesia and the world. Their video content is reviewing street food in certain places they have visited. Almost every week their channel uploads 3-4 videos about food review. The number of videos on their channel reached 945 videos on September 6, 2020 [7]. As Muslims, Evan and Tiwi try to get their faith into the videos. They do not only review street food but also give charity and spread positive messages through their interaction with the vendors. Many comments in their 
channel show positive vibes and like they have opened their conversation with the interviewees. This charity called Borong Semua is mostly liked by viewers and leads to philanthropy activities. It has influenced other YouTubers, including Baim Wong, to do the same. Here, the Hobby Makan viewers are not only from Indonesia but also come from Malaysia, Singapore, and Brunei Darussalam.

As a blessing to the Universe, caring and loving are parts of Islamic teaching. Prophet Muhammad (peace be upon him) has given a wonderful example of how Muslims should treat people and all God's creatures. It is mentioned on Al-Hujarat (49:13):

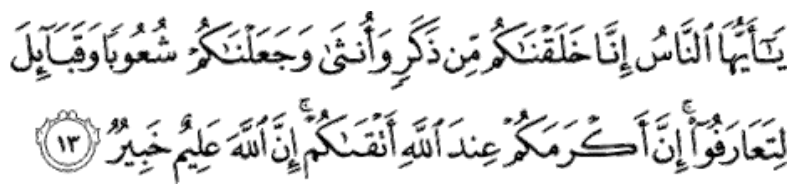

"O mankind, indeed We have created you from male and female and made you peoples and tribes that you may know one another. Indeed, the most noble ofyou in the sight of Allah is the most righteous of you. Indeed, Allah is Knowing and Acquainted".

In Islamic history, philanthropy has played a significant role in Islamic civilization. Philanthropy It has been carried out in different forms including education fund s, health care aid, humanitarian aid, social and community development. [8] The main goal of Islamic philanthropy is to raise the status of disadvantaged people and create social welfare in all aspects. This study attempts to illus trate how philanthropy is created using video visualization on Hobby Makan Channel.

Hobby Makan channel shows its altruism and piety through its philanthropic videos. Many viewers and other Youtubers are inspired by this channel to do the same. In terms of altruism, Moris, and Webb in Jannah (2016) [9] mentions all religions address their followers to have altruistic behavior. It is defined as an act of love, willing to help, and show good behavior. In this study, altruism which is presented through philanthropic activities is visualized by Evan and Tiwi in their YouTube videos.

\section{Research Method}

This research uses descriptive qualitative research methods, by describing the visualization of altruisms and piety in philanthropy of Hobby Makan Channel. Visualization of the video in this research is using the visual principles of a television program. The data in this study was collected through literature and observation on the Hobby Makan channel and YouTube videos in general. The triangulation method was used in analyzing data, by describing philanthropy actions shown in the video.

\section{Literature Review}

Is lamic Philanthropy is an act of dedication to do good deeds and care about people 's wellbeing in religious, social, and economic aspects. In Islamic theory, philanthropy is defined as helping the poor and needy, in both ritual and social dimensions. Ritual obligations stated in 
the Quran, shalat, and zakat (charity), for example, are acts of social and economic dedication to sharing wealth instead of keeping it by the rich [10]. Razaq [11] mentions Islamic philanthropy has been integrated and adapted to the Muslim society in Indonesia. At the beginning of Islam in Indonesia, forms of philanthropy including zakat, sadaqah, and infaq were practically implemented to help fight against poverty. In turn, they have developed into multiple sectors; healthcare, education, corporate social responsibility, culture, and politics. According to Hidayati, [12] philanthropy is an act to give something to others through sharing, loving, and caring behaviors. It aims at improving social welfare. Rubiyanah [13] says Islamic philanthropy as part of $d a$ 'wah. Max Muller and Sayyid Kuttub in Rubiyanah [13], describe dakwah as a sacred mission that needs to be done. In Islam, it is an obligation for every Muslim. Jahar [14], claims that philanthropy is not just love for humanity, but also an act of worship related to Muslim religious obligations. Qur'an mentions several principles of da'wah and communication; saying the right words, showing honesty, politeness, and calmness and giving solution. To call and invite people to be aware of and believe in God's commands needs to be done carefully to impress their heart; Qaulan Balighan (clear and firm words) and Qaulan Layyinan (gentle words), Qaulan Ma'rufan (polite words), Qaulan Maisuran (understandable words) and Qaulan Kariiman (noble words).

In Islam, altruism is mentioned in different words including Itsar, ihsan, infaq, and sodaqah. Itsar, for example, means to put the interest of others before one's interest. Ihsan is an act of kindness not only to humans but also to the environment, animals, and plants. Lastly, Infaq and sodaqah mean to give others what they need [9].

Philanthropy is not merely an expression of feeling by words. It needs to go with actions. In this modern era, it requires strategies and approaches to communicate with different types of social classes of people to send messages and call for engagement. To that end, the art of communication is a means to reach people. In communication, the message is classified into two forms, verbal (related to words and language) and non-verbal messages. The verbal messages, for example, are related to words, while non-verbal messages are described through gestures, colors, haptic, intonations, visual style, and alike (Curtis and B et al, 2006) [15]. This study uses the communication and $d a^{\prime}$ wah approach to analyze the philanthropy visualization on Hobby Makan Channel. Harold Laswell (Effendy, 2004) in Nurhadi and Kurniawan [16], is famous for his definition of communication, Who (says) What (to) Whom (in) Which Channel (with) What Effect. This definition describes five key factors of communication: 1. communicator, the one who sends the message, 2. message (verbal and non-verbal words), 3 . Audience (the one who receives the message), 4. Media, 5. Effect (cognitive, affective, and behavior changes). Alan $\mathrm{H}$ Monroe in Purnomo [17] formulates 5 strategies to create messages for the audience: (1) Attention, the message should captivate the audience's interest (2) Needs, to get the audience's attention, the message sender should know the audience's needs, including education, entertainment, social, and so on. (3) Satisfaction, the message should bring satisfaction to the audience. The information, for example, is presented with data and facts in the way the source is accountable. (4) Visualization, this strategy is how the message turns into a media, such as film, book, poster, advertisement, and alike. (5) Action, the next step is the message that could inspire the audience to act, buying the product, or watching the movie, for example. 
YouTubers with the most number of subscribers in today's electronic technology can serve as communicators and preachers. They send messages to the subscribers as audience and influence them at the same time. As communicators, YouTubers with lots of subscribers can make their videos to go viral. For this reason, if their videos have good messages and positive content, they will bring positive impacts. In contrast, if the videos are improper, they will get negative comments and the number of subscribers will gradually decrease. A YouTuber's background, in this regard, has a significant role in sending the video contents. Muslim YouTubers will share their message by associating them with religious content verbally or non-verbally. Muslim preachers generally share their messages dealing with religious issues on youtube. In other words, a YouTuber's personality and video content are inseparable [18].

Benkler (2011) and Cross (2011) in Nasrullah [19] consider the YouTube platform as a social media and media sharing. This platform distributes content and creates channels owned by users to share their page. There are several reasons how the contents are wanted and liked by social media users: (1) the contents are considered as important messages, (2) the contents show familiarity and association with the users, (3). the contents are used as a new database to share the information needed. Mandibergh (2012) in Nasrullah [19] defines social media as a means to fulfill mutual networking among users and inspire them to generate content.

Social media gives changes for nobody to somebody. Everybody can be a celebrity or influencer. The celebrity is even addressed as a religion in terms of followers ( (Nurhablisyah, 2014) [20]. Here, the celebrity concept is built through media. Celebrity is known as a person who has popularity in politics, entertainment, social, sport, and alike. The term of influencer is created on social media (Anjani\& Irwansyah, 2020). [21] An influencer is defined as a person who has the power to sell or promote goods or services on social media accounts. In today 's marketing process, an influencer is perceived as someone who has direct access to her/his followers to influence or to pursue them. There are several categories of influencer, (1) mega influencer, including public figure and celebrities who have already been popular among mass media, (2) macro influencer or opinion leader, influencer who has ability to communicate with more than 1 million followers, (3) micro influencer, someone who has small scale of followers $(1.000-10.000)$ and intensively communicate with the followers on social media. These influencers earn income form the brands and advertisement they represent.

Parra [22] illustrates how a YouTube channel can become a business strategy. There are several ways for YouTubers to make profits from their channels. The advertisement added to their video content will make them earn income. Once their channels attract users and advertisement enterprises, YouTubers deserve income from the advertisements, subscription fees, and merchandise. The more videos are uploaded, the more popular their channels will be among the subscribers and viewers.

Mabruri [23] argues that TV Programs, films, and videos have the same platform, but play different roles. A video is part of other types of film. It includes corporate profile, TV commercial, TV Program, and Music Video. There are 3 key factors of film affecting audiences; (1) visual, (2) audio, and (3) duration. The film creators do not only think about the production process but also consider the audience's preference. 
The video production process on YouTube is created based on the television production concept. In practice, television program production is a complicated procedure. It involves a lot of people and cost a lot of budgets. On YouTube, however, everybody can make their video with a minimum budget and cost. In terms of audiovisual media, the visualization of video uploaded on YouTube should adopt the broadcas ting principles. Wurtzel in Latief and Utud [24] illustrates four major stages in the non-dramatic television process: (1) preproduction planning, (2) setting up and rehearsal, (3) production, and (4) post-production. In the pre-production stage, for example, creators should plan the basic idea of the content. There are a lot of video contents on YouTube; interview and discussion on a trending topic, humor, culinary, music, religious shows, traveling, sport, and so on. They should write down the idea and put it into the shooting plan. In the second stage, rehearsal, they could practice and test the planning before video shooting takes place. In the production stage, they should prepare all the things related to production, including lighting, equipment, audio, crews, and so on. Luckily, YouTube video makers could work on their own using smartphones and applying nat ural light from the sun or flash. The fourth stage is the post-production or editing process. In this stage, the creators use a computer program to edit their videos and audios. Editing videos do not only focus on video lighting, effects, and audio leveling but also on applying texts, animations, etc.

To create a good program, YouTubers should apply creative thinking. Alex F. Osborn in Latief and Utud [24], mentions a formula to produce creative videos, known as SCAMPER; Substitution (substituting another program/video), Combination (combining several types of program or video, such as an interview with games or cooking with interview), Adaptation (adapting another video or program), Modification (modifying a well-known video), Practice for another user ( sharing goods and money to help others), Elimination (to add or edit video component), and Reverse (giving a different display to build different atmosphere).

In term of TV program visualization, Fachruddin [25] mentions shot or visual plays a very important role in the TV program. There are several principles in which the camera represents the audience's perspective to understand the phenomenon or theme. The principles are (1) focus, which means the shot should be sharp and clear, (2) Irish (natural and bright), (3) shot size, (4) composition, (5) stability, (6) camera movement, (7) continuity, and (8) motivation. In this study, the authors demonstrate one video from Hobby Makan Channel as the main theme which was uploaded in August 2020 and presented Borong Semua (All of Them) from 2019-2020.

\section{Result and Discussion}

Hobby Makan Channel with Borong Semua as a tagline uploads videos on Youtube as an act of philanthropy. Each video has already got viewers. In creating Borong Semua videos, Evan and Tiwi spend and share IDR1.000.000,- for every street food vendors they have met. If 3 videos are created each week, there would be 12 videos in a month. It means it would cost about IDR12.000.000,- each month. According to socialblade.com [26], the average income of Hobby Makan Channel is $\$ 3.700-58.700$ each month. The income is then allocated to cover the production budget. 
The production budget is considered an important factor in creating a program. Mabruri [23] claims that self-produced videos need to consider the budget carefully. At a TV company, the production will follow procedures; discussion among the personnel and officers, and approval from the management. YouTubers, in contrast, work on their behalf and all risks are therefore handled on their own. Compared to TV, youtube may cost a minimum budget for simple equipment, talents, location, and software editing. Many YouTubers create programs from pre-production to post-production involving only a few personnel. If the videos get good comments and bring more viewers, the YouTubers will earn a higher income. This income can be used for production and cover the operational cost.

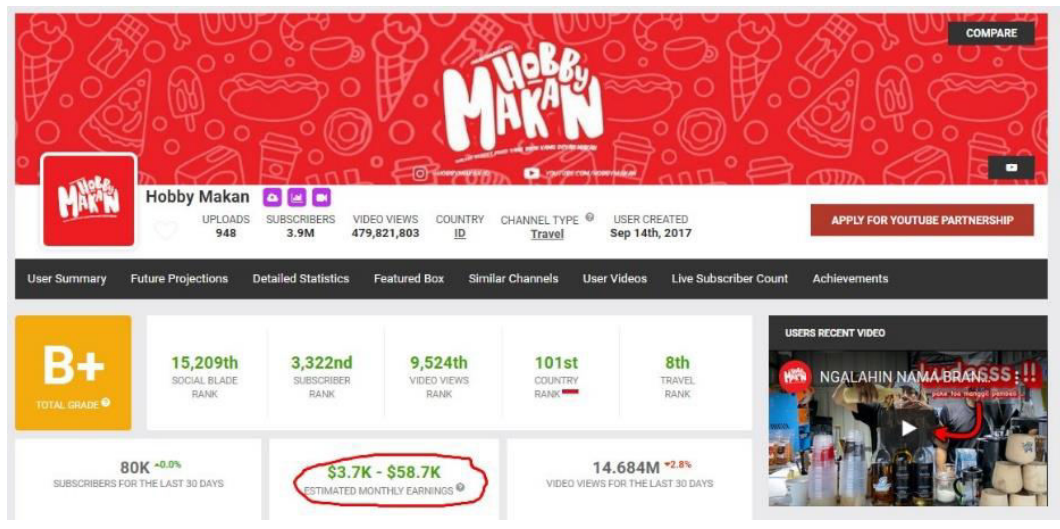

Fig. 2. Hobby Makan Channel Socialblade.com

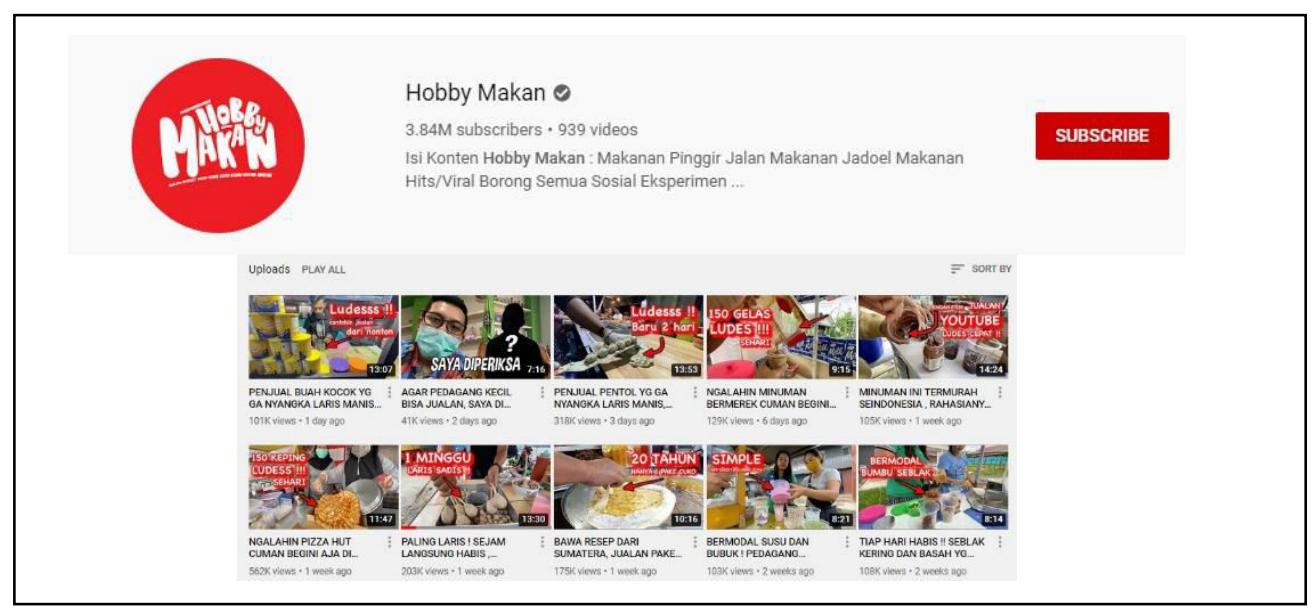

Fig. 3. Hobby Makan Channel and Thumbnail 
Hobby Makan Channel presents several themes ranging from cooking, traveling, food tasting, and Borong Semua. Working together with Ojol/Ojek Online (online driver), following the government regulations due to the Covid-19 pandemic where everybody must stay at home, Hobby Makan Channel is created to make people stay at home and enable them to order food by online service delivery. As the new normal started in July 2020, the channel has continued to do street food review by applying health protocol for Covid -19 . The average duration of the videos is 10-15 minutes. The visualization of Ngalahin Pentol Terlaris, Cara Bikinnya Gak Ada Yang Seperti Ini di Pinggir Jalan video uploaded on August 28, 2020, for example, is illustrated as follows:

Table 1. Visualization of Ngalahin Pentol Terlaris, Cara Bikinnya Gak Ada Yang Seperti Ini di Pinggir Jalan Video by Hobby Makan Channel

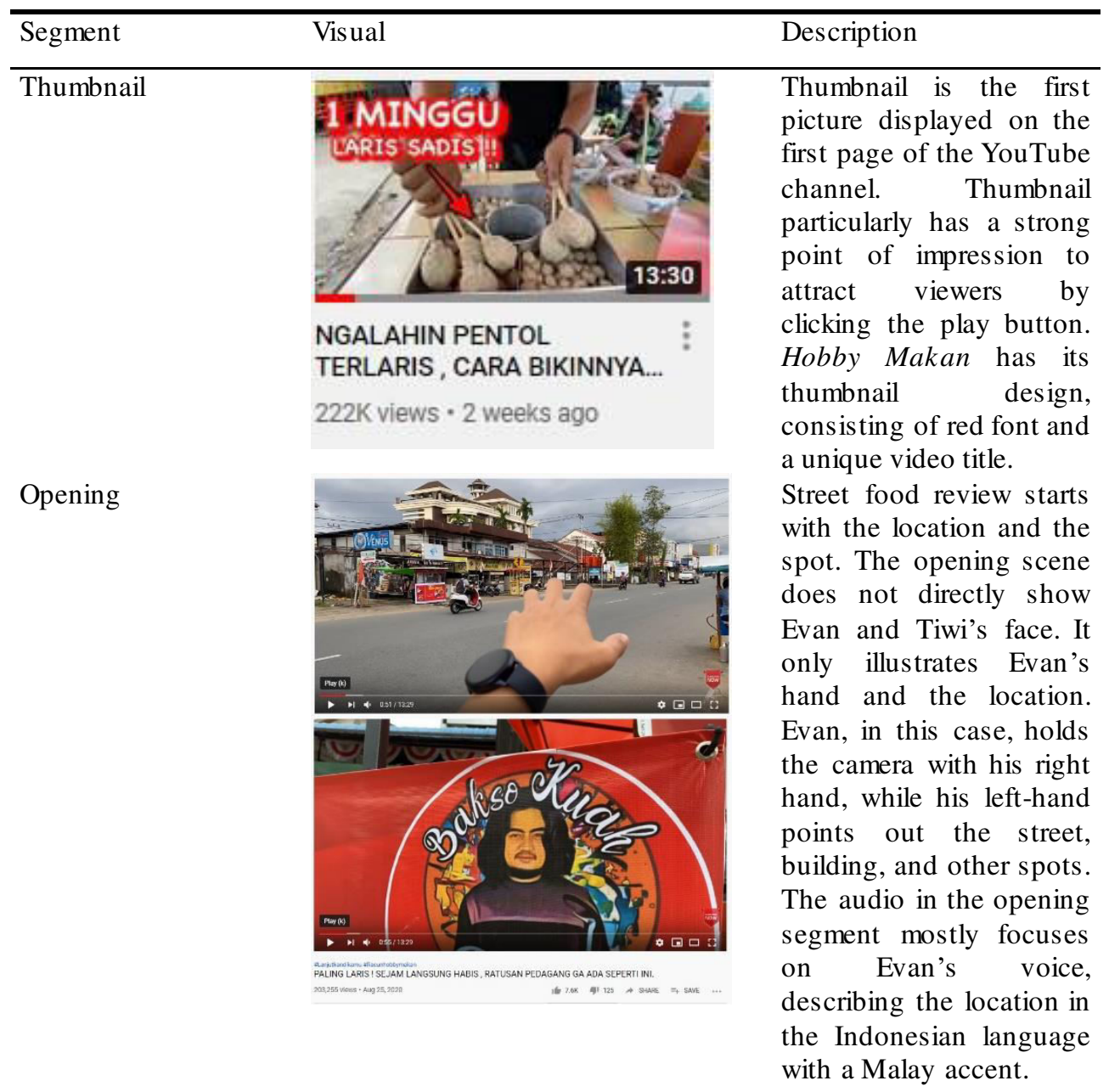




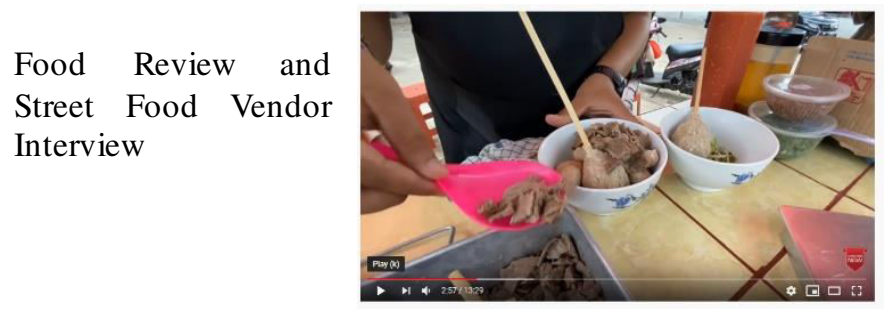

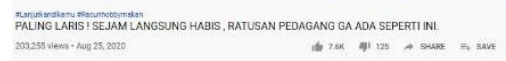
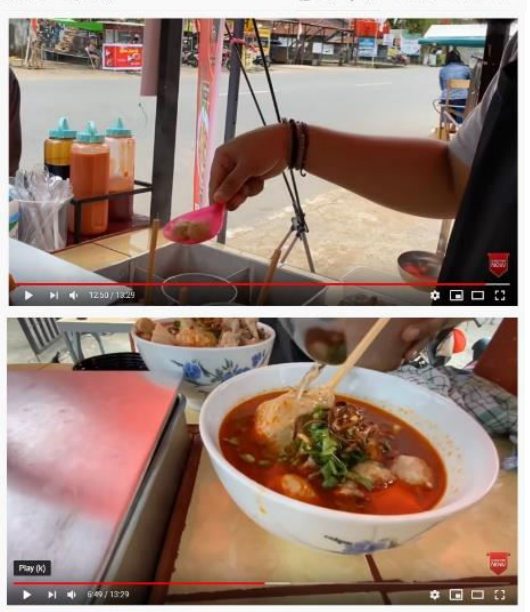

PALING LARISI ISEJAM LANGGUNG HABIS, RATUSAN PEDAGANG GA ADA SEPERTIINU.

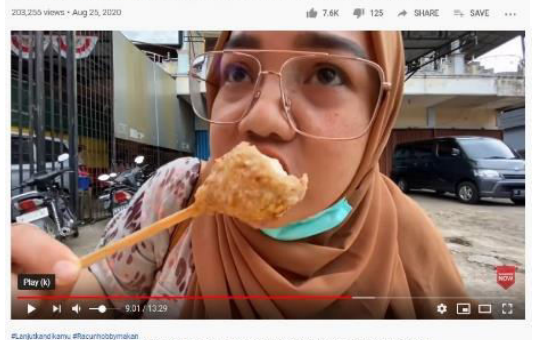

PALING LARIS ISEAMM LANGSUNG HABIS, RATUSAN PEDAGANG GA ADN SERERTIIN.

Closing
Almost all food review is about testing the food, food price, food texture, and main ingredients. The shot angle mostly goes close-up to medium close-up.

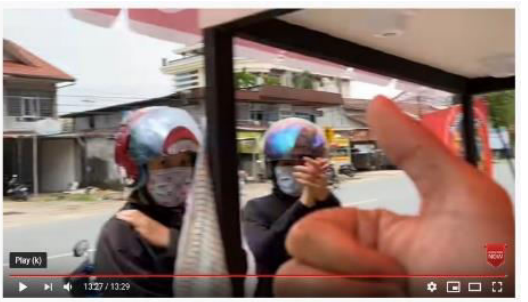

In the closing segment, Evan pays the sellers for all the food left and gives it for free to other customers. The closing statement is gratitude, wishes, and goodbye. 


\section{Conclusions}

The Philanthropy Visualization on Hobby Makan Channel is represented on Borong Semua videos. The videos start with a street food review and end with the situation where the Hobby Makan channel owners buy all the food left and give it to other customers. Here, the authors conclude the study with the followings:

1. Philanthropy visualization is shown as a means of sharing and caring for the street food vendors and other customers in the videos uploaded on the Hobby Makan channel. The amount of money spent on the food is collected from YouTube income through the number of viewers and subscribers.

2. The act of philanthropy visualized on Hobby Makan videos demonstrates altruism and piety which attract users to get involved in religious activities, kindness, and solidarity.

3. Hobby Makan channel does not only give charity but also informs viewers about the food and the street vendors.

4. The channel owners develop a new technique of religious communication through verbal and non-verbal messages. The video contents have been used as a tool to send messages among online media users

5. YouTube video production process is similar to the one in the TV program and film production. There are three key factors; video, audio, and duration. The average duration of Hobby Makan videos is about 10-15 minutes. Most of the videos were shot during the day on a mobile phone or video camera. The brightness and sharpness of the videos are considered as good lighting with composition. Hobby Makan channel commonly uses medium close-up and close-up shots to capture objects. By using minimum property, the channel can save production cost which eventually enables it to focus on street food review and give charity. 


\section{References}

[1] P. Perilaku and P. I. Indonesia, "Penetrasi \& profil perilaku pengguna internet indonesia," 2018.

[2] I. Mujahid et al., "MUBALIG YOUTUBEDAN KOMODIFIKASI KONTEN DAKWAH," $A l$ Balagh, vol. 4, no. 1, pp. 91-120, 2019.

[3] L. Fitzpatrick, "Brief History YouTube," Time Magazine, 2010. [Online]. Available: http://content.time.com/time/magazine/article/0,9171,1990787,00.html. [Accessed: 20-Aug-2020].

[4] ChannelMeter, "YouTube's Top Countries," ChannelMeter, 2019. [Online]. Available: https://medium.com/@ChannelMeter/youtubes-top-countries-47b0d26dded. [Accessed: 20-Aug2020].

[5] W. K. PERTIWI, "Penonton Bulanan YouTube Tembus Angka 2 Miliar,"kompas.com, 2019. [Online]. Available: https://manado.kompas.com/read/2019/05/09/16120017/penonton-bulanany outube-tembus-angka-2-miliar. [Accessed: 20-Aug-2020].

[6] M. Tarigan, "10 Youtuber Indonesia dengan Penghasilan Paling Tinggi di 2019," 2019. [Online]. Available: https://gay a.tempo.co/read/1289071/10-y outuber-indonesia-denganpenghasilan-paling-tinggi-di-2019. [Accessed: 20-Aug-2020].

[7] H. Makan, "Hobby Makan Profile," 2017. [Online]. Available: https://www.youtube.com/channel/UCNYvkAHBuLfOzUBuR1Uvv9w. [Accessed: 20-Aug-2020].

[8] A. S. Jahar, "Marketing Islam through Zakat Institutions in Indonesia," Stud. Islam., vol. 22, no. 3, pp. 405-442, 2015.

[9] M. Jannah, "KONSEP ALTRUI SME DALAM PERSPEKTIF AL QUR'AN Kajian Integratif Antara Islam dan Psikologi," Universitas Islam Negeri Maulana Malik Ibrahim Malang, 2016.

[10] A. S. Jahar, "Developing Islamic Philanthropy for Human Rights: The Indonesian Experience," in International Conference on Law and Justice (ICLJ 2017), 2017, pp. 1-4.

[11] A. Razzaq, "Pengembangan Model Pembangunan Ummat Melalui Lembaga Filantropi Islam Sebagai Bentuk Dakwah bil Hal," Intizar, vol. 20, no. 1, pp. 163-179, 2014.

[12] O. N. Hidayati and I. Surakarta, "Filantropi Dakwah dan Kaum Minoritas di Indonesia," Academica, vol. 1, no. 2, pp. 221-230, 2017.

[13] Rubiyanah (Universitas Syarief Hidayatullah), "DAKWAH BERBASIS KEMANUSIAAN: STUDI TERHADAP AKSI KEM ANUSIAAN MEDICAL EMERGENCY RESCUE COM MITTEE (MER-C) INDONESIA DI GAZA (2009-2015) DAN LOMBOK (2018)," UIN Sy arief Hiday atullah, Jakarta, 2019.

[14] A. Z. M. Raden, M. I. Qeis, and A. S. Jahar, "Philanthropic Ads and Social Welfare: How Digital Advertising Promotes Islamic Philanthropy in Indonesia," in 1st International Conference on Recent Innovations (ICRI 2018), 2018, pp. 2459-2466.

[15] S. Asiyah, P. Magister, and K. Dan, "IMPLEMENTASI KOMUNIKASI VERBAL DAN NONVERBAL DALAM KEGIATAN PUBLIC SPEAKING SANTRI DI PONDOK PESANTREN DARUL FALAH," Walisongo Semarang, 2018.

[16] Z. F. Nurhadi, A. W. Kurniawan, P. Studi, I. Komunikasi, and U. Garut, "Jurnal Komunikasi Hasil Pemikiran dan Penelitian-ISSN: 2461-0836 2017 KAJIAN TENTANG EFEKTIVITAS PESAN DALAM KOMUNIKASI," J. Komun. Has. Pemikir. dan Penelit., vol. 3, no. 1, pp. 90-95, 2017.

[17] J. W. Purnomo, "PERSEPSI PEREMPUAN KELURAHAN LOA BAKUNG KOTA SAMARINDA MENGENAI PESAN IKLAN TELEVISI ANLENE ONE-A-DAY," eJournal Ilmu Komunikas, vol. 1, no. 2, pp. 276-294, 2013.

[18] M. N. Rahmah, "Kredibilitas Juru Dakwah sebagai Komunikator," Alhadharah J. Ilmu Dakwah, vol. 12, no. 24, pp. 1-13, 2013.

[19] R. Nasrullah, Media Sosial Perspektif Komunikasi, Budaya, dan Sosioteknologi, 1st ed. Bandung: Simbiosa Rekatama, 2015.

[20] Nurhablisyah, "Video 'Mpo Alpa' dan Fenomena Selebritis Online Indonesia," J. Magenta, STMK Trisakti, vol. 2, no. 02, pp. 347-354, 2018. 
[21] S. Anjani, "MENGKOMUNIKASIKAN PESAN DI MEDIA SOSIAL INSTAGRAM [ THE ROLE OF SOCIAL MEDIA INFLUENCERS IN COMMUNICATING MESSAGES USING INST AGRAM ]," POLYGLOT J. Ilm., vol. 16, no. 2, pp. 203-229, 2020.

[22] P. N. Parra, "YouTube: The Business Model," pp. 58-62, 2015.

[23] A. Mabruri KN, Manajemen Produksi Program Acara TV Format Acara Drama, 1st ed. jakarta: PT Grasindo, 2013.

[24] L. Rusman and U. Yustiatie, Siaran televisi non-drama: kreatif, produksi, public relations, dan iklan, 2nd ed. Jakarta: PT Prenadamedia Group, 2015.

[25] A. Fachruddin, Dasar-dasar Produksi Televisi Produksi berita, Feature, Laporan Investigasi, Dokumenter, dan Teknik Editing, 2nd ed. Jakarta: PT Prenada Media Utama, 2014.

[26] social blade, "Social Blade Hobby Makan," 2020. [Online]. Available: https://socialblade.com/y outube/channel/UCNYvkAHBuLfOzUBuR1Uvv9w. [Accessed: 08-Sep2020]. 